\title{
ЗАКОННЫЕ ПРЕДСТАВИТЕЛИ НЕСОВЕРШЕННОЛЕТНИХ УЧАСТНИКОВ УГОЛОВНОГО СУДОПРОИЗВОДСТВА
}

\author{
Н. Ю. Литвинцева \\ Байкальский государственный университет, г. Иркутск, Российская Федерация
}

\section{Информация о статье}

Дата поступления

29 мая 2017 г.

Дата принятия к печати 20 ноября 2017 г.

Дата онлайн-размещения 27 ноября 2017 г.

\section{Ключевые слова}

Уголовное судопроизводство; участники уголовного судопроизводства; несовершеннолетние участники уголовного судопроизводства; законные представители несовершеннолетнего подозреваемого, обвиняемого, потерпевшего, свидетеля

\begin{abstract}
Аннотация
В статье рассматриваются актуальные проблемы защиты прав и законных интересов несовершеннолетних участников уголовного судопроизводства, понятие несовершеннолетних участников уголовного судопроизводства, под которыми понимаются несовершеннолетние подозреваемые, обвиняемые, потерпевшие, свидетели. Анализируются гарантии прав несовершеннолетних участников уголовного судопроизводства. Исследуется процессуальный статус законных представителей несовершеннолетних подозреваемых, обвиняемых, потерпевших и свидетелей. Аргументируется необходимость привлечения в качестве законного представителя близкого родственника, родственника или лица, которое фрактически принимает участие в воспитании несовершеннолетнего и заботится о нем. Отстаивается позиция об обязательности участия в производстве по уголовному делу законных представителей несовершеннолетних свидетелей. Следует закрепить в УПК РФ единообразный порядок привлечения законных представителей, который предусматривал бы во всех случаях в обязательном порядке вынесение следователем, судом постановления о допуске законного представителя несовершеннолетнего в качестве участника уголовного судопроизводства. Обосновывается необходимость внесения изменений в нормы УПК РФ, регулирующие правовое положение законных представителей несовершеннолетнего подозреваемого, обвиняемого, потерпевшего, свидетеля. Предлагается включить в УПК РФ ст. 56', закрепляющую процессуальный статус законных представителей свидетеля.
\end{abstract}

\section{LEGAL REPRESENTATIVES OF MINOR PARTICIPANTS OF CRIMINAL J USTICE PROCESS}

\author{
Natalia Y. Litvintseva \\ Baikal State University, Irkutsk, Russian Federation
}

\section{Article info}

Received

May 29, 2017

Accepted

November 20, 2017

Available online

November 27, 2017

\section{Keywords}

Criminal justice process; participants in criminal justice process; minor participants in criminal justice process; legal representatives of a minor suspect, the accused, victim, witness

\begin{abstract}
The article deals with current problems of protection of rights and legitimate interests of minor participants of the criminal justice process. The author defines the concept of minor participants of the criminal justice process who are understood as minor suspects, defendants, victims, and witnesses; and analyzes the guarantees of the rights of its minor participants. The author also studies the procedural status of lawful representatives of minor suspects, defendants, victims and witnesses; and gives reasons why a close relative, a relative or a person who actually takes part in upbringing and care of the minor should become a lawful representative. The author maintains her position as to why participation of lawful representatives of minor witnesses in conduct of criminal proceedings is a must. A uniform order of involvement of lawful representatives should be regularized in the Code of Criminal Procedure of the Russian Federation which would provide in all cases without fail a resolution on the admission of the lawful representative of the minor as a participant of criminal legal proceedings issued by the investigator or the court. The need
\end{abstract}


for modification of the norms of the Criminal Procedure Code of the Russian Federation regulating the legal status of lawful representatives of the minor suspect, defendant, victim, witness is proved. The author offers to include Article $56^{1}$ into the Code of Criminal Procedure of the Russian Federation that would set the procedural status of lawful representatives of the witness.

Одной из важных гарантий осуществления прав несовершеннолетних участников уголовного судопроизводства является участие в нем их законных представителей. Как справедливо отмечает Э. Б. Мельникова, участие законного представителя несовершеннолетнего в российском уголовном судопроизводстве связано с двумя обстоятельствами: 1) с неполнотой процессуальной дееспособности несовершеннолетнего; 2) с тем, что законный представитель (родители, усыновители, опекуны, попечители) несет ответственность за воспитание и поведение несовершеннолетнего [1, с. 70-71].

В соответствии с Толковым словарем русского языка представитель - это «лицо, которое действует по чьему-нибудь поручению, выражает чьи-нибудь интересы, взгляды»; законный - «основывающийся на законе» [2, с. 210-211, 579]. Исходя из этого законный представитель - это лицо, действующее на основании закона в интересах другого лица, в анализируемом случае несовершеннолетнего участника уголовного судопроизводства.

Некоторые авторы к достоинствам современного российского уголовно-процессуального законодательства относят подробную регламентацию процедуры участия законного представителя несовершеннолетнего [3, с. 142]. С указанным суждением сложно согласиться, поскольку процессуальное положение законного представителя несовершеннолетнего участника уголовного судопроизводства видится весьма схематичным, требующим уточнения целого ряда положений.

Согласно п. 12 ст. 5 УПК РФ, законные представители - это родители, усыновители, опекуны или попечители несовершеннолетнего подозреваемого, обвиняемого либо потерпевшего, представители учреждений или организаций, на попечении которых находится несовершеннолетний подозреваемый, обвиняемый либо потерпевший, органы опеки и попечительства.

В юридической литературе отмечается, что перечень лиц, указанных в п. 12 ст. 5 УПК РФ, является исчерпывающим, поэтому на практике при решении вопроса о том, кто может быть признан законным представителем несовершеннолетнего, необходимо ру- ководствоваться требованиями этого пункта [4, с. $42 ; 5$, с. 245].

В постановлении Пленума Верховного Суда РФ от 1 февраля 2011 г. № $1^{11}$ (в ред. постановления Пленума Верховного Суда Рф от 2 апреля 2013 г. № 6) содержится разъяснение, согласно которому, если несовершеннолетний подсудимый не имеет родителей и проживает один или у лица, не назначенного надлежащим образом его опекуном или попечителем, в суд в качестве его законного представителя вызывается представитель органа опеки или попечительства.

Другие авторы придерживаются иной точки зрения. Так, А. А. Баев, справедливо полагая, что понятие законных представителей несовершеннолетних участников уголовного судопроизводства нуждается в уточнении, предлагает включить в перечень законных представителей близких родственников, родственников и близких лиц [6, с. 8-9, 21].

Солидаризируясь с ним, А. Г. Назарчук полагает, что близкие родственники, вовлеченные в уголовное судопроизводство в качестве законных представителей несовершеннолетних подозреваемых, обвиняемых, могли бы оказать следователю действенную помощь в установлении психологического контакта, в выяснении комплекса вопросов, касающихся личности несовершеннолетнего, условий его жизни и воспитания, обстоятельств и причин совершения им преступления [7, с. 203].

Е. В. Марковичева считает целесообразным перечень законных представителей дополнить приемными родителями несовершеннолетних [8, с. 24].

Несмотря на то что в п. 12 ст. 5 УПК РФ не указаны близкие родственники, родственники и близкие лица несовершеннолетнего, на практике они признаются законными представителями. В этой связи Р. В. Мазюк замечает, что примерно в 80 \% уголовных дел в отношении несовершеннолетних законными представителями выступают родители подозреваемого, обвиняемого. На первый взгляд, это является логичным и закономерным, вместе с тем, как верно подчеркивает

1 О судебной практике применения законодательства, регламентирующего особенности уголовной ответственности и наказания несовершеннолетних // Бюллетень Верховного Суда РФ. 2011 . № 4. С. 4. 
указанный автор, если фрактическим воспитанием несовершеннолетнего занимается его бабушка или тетя, не имеющая статуса опекуна, то очевидно, что она в наибольшей степени может защитить права и законные интересы несовершеннолетнего, чем его неблагополучные родители [9, с. 126, 128].

Следует заметить, что касательно категории дел о применении принудительных мер медицинского характера УПК РФ содержит нормы, предполагающие возможность наделения близкого родственника процессуальным статусом законного представителя. В частности, в ч. 1 ст. 437 предусмотрено, что «при отсутствии близкого родственника законным представителем может быть признан орган опеки и попечительства». К числу законных представителей УПК РФ относит представителей учреждений или организаций, на попечении которых находится несовершеннолетний подозреваемый, обвиняемый либо потерпевший, органы опеки и попечительства (п. 12 ст. 5).

На практике возникает вопрос об эффективности привлечения представителей учреждений или организаций, на попечении которых находится несовершеннолетний подозреваемый, обвиняемый, а также органов опеки и попечительства в качестве законных представителей, вызывает сомнение их заинтересованность представлять интересы несовершеннолетнего подозреваемого, обвиняемого. Справедливой в этой связи видится позиция авторов, утверждающих, что участие незаинтересованных лиц в качестве законных представителей не может обеспечить должным образом защиту прав несовершеннолетних и поэтому носит формальный характер [10, с. 116]. Так, следует поддержать позицию Е. В. Марковичевой о том, что привлечение в качестве законного представителя работника органа опеки и попечительства должно проводиться только в исключительных случаях [11, с. 281].

Думается, что привлечение в качестве законного представителя близкого родственника, родственника или лица, которое фактически принимает участие в воспитании несовершеннолетнего и заботится о нем, более целесообразно.

На основании вышеизложенного представляется необходимым внести изменения в п. 12 ст. 5 УПК РФ, дополнив перечень законных представителей близкими родственниками, родственниками и близкими лицами, принимающими непосредственное участие в уходе за несовершеннолетним и в его воспитании.
Анализ п. 12 ст. 5 УПК РФ дает основание утверждать, что законные представители осуществляют защиту прав и законных интересов только несовершеннолетнего подозреваемого, обвиняемого либо потерпевшего. В рассматриваемой норме в числе представляемых лиц отсутствуют несовершеннолетний свидетель, совершеннолетние лица с психическими или фризическими недостатками, а также лица, в отношении которых осуществляется производство о применении принудительных мер медицинского характера.

Вместе с тем в ст. 191, 280 и 437 УПК РФ указано, что в допросе несовершеннолетнего свидетеля, лица, в отношении которого осуществляется производство о применении принудительных мер медицинского характера, участвует его законный представитель. Так, по уголовным делам о преступлениях, совершенных несовершеннолетними, к обязательному участию в уголовном деле привлекаются их законные представители (ст. 48 УПК РФ), процессуальный статус которых закреплен в ст. 426 и 428 УПК РФ.

Законный представитель лица, в отношении которого осуществляется производство о применении принудительных мер медицинского характера, также привлекается к обязательному участию (ст. 437 УПК РФ).

При производстве допроса, очной ставки, опознания и проверки показаний несовершеннолетнего потерпевшего или свидетеля вправе присутствовать его законный представитель (ч. 1 ст. 191 УПК РФ), а допрос несовершеннолетнего потерпевшего или свидетеля, не достигшего возраста 14 лет, проводится с его обязательным участием (ч. 4 ст. 280 УПК РФ). Заметим, что для защиты прав и законных интересов несовершеннолетних потерпевших к обязательному участию в уголовном деле привлекаются их законные представители (4. 2 ст. 45 УПК РФ), следовательно, при допросе несовершеннолетнего потерпевшего участие законного представителя является обязательным. Думается, что и несовершеннолетний свидетель, независимо от возраста, нуждается в установлении дополнительных гарантий защиты его прав и законных интересов. В этой связи представляется, что следственные действия с участием несовершеннолетних потерпевших и свидетелей, независимо от их возраста, должны проводиться с обязательным участием их законных представителей.

В УПК РФ недостаточно полно определено участие законных представителей совершеннолетних лиц с психическими или физическими недостатками, лиц, признанных 
недееспособными или ограниченно дееспособными, т. е. таких лиц, которые по своему состоянию лишены возможности самостоятельно защищать свои права и законные интересы. Наряду с этим законодатель предусматривает дополнительные гарантии защиты прав и законных интересов потерпевших, находящихся в зависимом или беспомощном состоянии или по своему физическому или психическому состоянию лишенных возможности самостоятельно защищать свои права и законные интересы, лиц, признанных недееспособными или ограниченно дееспособными (ч. 4 ст. 20, ч. 3 ст. 44, ч. 2 ст. 45 УПК РФ). Следует заметить, что указанные гарантии необходимо предусмотреть и в отношении свидетеля, который по своему физическому или психическому состоянию не может отстаивать свои права и законные интересы.

Таким образом, участвующие в уголовном судопроизводстве законные представители осуществляют защиту прав и законных интересов, во-первых, несовершеннолетних подозреваемых, обвиняемых, подсудимых, потерпевших, свидетелей, а во-вторых, лиц, которые по своему физическому или психическому состоянию лишены возможности самостоятельно защищать свои права и законные интересы, и лиц, в отношении которых осуществляется производство о применении принудительных мер медицинского характера. Соответственно, перечень представляемых лиц, перечисленных в п. 12 ст. 5 УПК РФ, нуждается в дополнении.

Законодатель, определяя вступление законных представителей несовершеннолетних свидетелей ${ }^{2}$ в уголовное судопроизводство, употребляет словосочетания «вправе присутствовать» и «обязательно участвует» (ч. 1 ст. 191, ч. 4 ст. 280 УПК РФ). В этой связи следует заметить, что «присутствие» и «участие» не являются синонимами: «присутствие» - это пребывание, нахождение в каком-либо месте, “участие» - совместная с кем-нибудь деятельность, сотрудничество в чем-нибудь $[2$, с. 598,843$]$.

Употребление законодателем разносмысловых слов представляется нелогичным, поскольку законный представитель несовершеннолетнего свидетеля привлекается для осуществления активных действий по защите его прав и законных интересов, а не

2 УПК РФ закрепляет обязательное участие законных представителей несовершеннолетних подозреваемых, обвиняемых, подсудимых, потерпевших, а также лиц, в отношении которых осуществляется производство о применении принудительных мер медицинского характера (ч. 2 ст. 45, ст. 48, ч. 1 ст. 437). для пассивного присутствия на следственном действии. В частности, законный представитель вправе возражать против применения видеозаписи или киносъемки при производстве следственных действий с участием несовершеннолетнего свидетеля; вправе с разрешения председательствующего задавать вопросы допрашиваемому (ч. 5 ст. 191, 4. 4 ст. 280 УПК РФ). Кроме того, законный представитель имеет возможность контролировать продолжительность производства следственных действий с участием несовершеннолетнего свидетеля, которая ограничена ч. 1 ст. 191 УПК РФ. Таким образом, более предпочтительным с точки зрения юридической техники в тексте УПК РФ представляется использование слова «участие» законных представителей в уголовном судопроизводстве.

В УПК РФ отсутствует единообразный порядок привлечения законных представителей. Так, законные представители несовершеннолетнего подозреваемого, обвиняемого, а также лица, в отношении которого ведется производство о применении принудительной меры медицинского характера, допускаются к участию в уголовном деле на основании постановления следователя либо суда (ч. 1 ст. 426, ч. 1 ст. 437 УПК РФ). Вынесение постановления о привлечении законных представителей несовершеннолетних подсудимых, потерпевших, свидетелей законом не предусмотрено. Предполагается, что во всех этих случаях в обязательном порядке следователь, суд, допуская законного представителя несовершеннолетнего в качестве участника уголовного судопроизводства, должен вынести постановление. В этой связи следует отметить, что отстранить законного представителя от участия в уголовном судопроизводстве возможно только на основании постановления.

Необходимо заметить, что существуют случаи, когда участие законного представителя в допросе несовершеннолетнего признается нецелесообразным. Во-первых, следователь не допускает к участию в допросе несовершеннолетнего потерпевшего или свидетеля его законного представителя, если это противоречит интересам несовершеннолетнего потерпевшего или свидетеля. В этом случае следователь обеспечивает участие в допросе другого законного представителя несовершеннолетнего потерпевшего или свидетеля (ч. 3 ст. 191 УПК РФ). Во-вторых, законный представитель несовершеннолетнего потерпевшего, подозреваемого, обвиняемого, подсудимого отстраняется от участия 
в уголовном деле, если его действия наносят ущерб интересам несовершеннолетних. В этом случае к участию в уголовном деле допускается другой законный представитель (ч. 2.2 ст. 45, ч. 4 ст. 426, ч. 2 ст. 428 УПК РФ).

Постановлением Пленума Верховного Суда РФ от 1 февраля 2011 г. № 1 разъясняется, что к действиям, наносящим ущерб интересам несовершеннолетнего, следует относить невыполнение обязанностей, вытекающих из статуса законного представителя, в том числе по воспитанию несовершеннолетнего, либо уклонение от участия в деле в качестве законного представителя, а равно злоупотребление процессуальными и иными правами, отрицательное влияние на несовершеннолетнего, создание препятствий для выяснения обстоятельств, имеющих значение для дела. Недопустимо привлечение к участию в деле в качестве законных представителей лиц, которые совершили преступление совместно с несовершеннолетним, а также лиц, в отношении которых несовершеннолетний совершил преступление ${ }^{3}$. Представляется, что аналогичные правила должны распространяться и на случаи отстранения законного представителя лица, в отношении которого ведется производство о применении принудительной меры медицинского характера.

В этой связи необходимо поддержать позицию Е. В. Марковичевой о том, что выбор другого законного представителя несовершеннолетнего должен осуществляться с учетом мнения самого несовершеннолетнего [11, с. 282]. Думается, что и первоначально, привлекая законного представителя к участию в допросе несовершеннолетнего, разумно выяснить мнение самого несовершеннолетнего о выборе его законного представителя ${ }^{4}$. Также вызывают интерес суждения А. Б. Шлипкиной, которая предлагает для определения наилучшего претендента в законные представители (кого из двух родителей допустить в качестве законного представителя; кого из представителей организации, на попечении которой находится несовершеннолетний, выбрать; кого допустить в качестве законного представителя, если несовершеннолетний возражает против участия выбранного законного представителя) составлять «карту законного представителя», отражающую сведения о характеристике

${ }^{3}$ О судебной практике применения законодательства, регламентирующего особенности уголовной ответственности и наказания несовершеннолетних.

${ }^{4}$ Спорной и неубедительной представляется позиция А. Г. Назарчука, утверждающего, что советоваться с подростком по данным вопросам некорректно и нецелесообразно [7, с. 203]. личности претендентов в законные представители; о мнении несовершеннолетнего относительно участия каждого из претендентов в качестве его законного представителя; о возможности привлечения нескольких лиц в качестве законных представителей и т. д. [12, с. 115].

Процессуальный статус законного представителя, его права и обязанности вытекают из процессуального статуса лица, чьи интересы он представляет.

Вместе с тем процессуальный статус законных представителей несовершеннолетних в УПК РФ отражен весьма поверхностно. Так, законные представители потерпевшего, гражданского истца и частного обвинителя имеют те же процессуальные права, что и представляемые ими лица (4. 3 ст. 45 УПК РФ). Статья 48 УПК РФ закрепляет, что законные представители несовершеннолетних подозреваемых и обвиняемых привлекаются к обязательному участию в уголовном деле в порядке, установленном ст. 426, 428 УПК РФ. Часть 2 ст. 437 УПК РФ устанавливает права законного представителя лица, в отношении которого ведется производство о применении принудительной меры медицинского характера. Процессуальный статус законного представителя несовершеннолетнего свидетеля при этом не сфоормулирован.

К правам законных представителей несовершеннолетних потерпевших либо лиц, по своему физическому или психическому состоянию лишенных возможности самостоятельно защищать свои права и законные интересы, относятся право участвовать в уголовном преследовании, а по уголовным делам частного обвинения - выдвигать и поддерживать обвинение (ст. 22 УПК РФ); право ходатайствовать об обеспечении дознавателем, следователем или судом участия адвоката в качестве представителя несовершеннолетнего потерпевшего, не достигшего возраста 16 лет, в отношении которого совершено преступление против половой неприкосновенности (ч. 2.1 ст. 45 УПК РФ); а также права потерпевшего в полном объеме (ч. 2 ст. 42 УПК РФ).

В ст. 426 и 428 УПК РФ, регулирующих участие законного представителя несовершеннолетнего подозреваемого, обвиняемого, подсудимого, в перечне прав законного представителя закреплено: 1) право знать, в чем подозревается или обвиняется несовершеннолетний; 2) присутствовать при предъявлении обвинения; 3) участвовать в допросе несовершеннолетнего подозреваемого, обвиняемого, а также с разрешения 
следователя в иных следственных действиях, производимых с его участием и участием защитника; 4) знакомиться с протоколами следственных действий, в которых он принимал участие, и делать письменные замечания о правильности и полноте сделанных в них записей; 5) заявлять ходатайства и отводы, приносить жалобы на действия (бездействие) и решения дознавателя, следователя, прокурора; 6) представлять доказательства; 7) по окончании предварительного расследования знакомиться со всеми материалами уголовного дела, выписывать из него любые сведения и в любом объеме; а также в судебном заседании: 1) заявлять ходатайства и отводы; 2) давать показания; 3) представлять доказательства; 4) участвовать в прениях сторон; 5) приносить жалобы на действия (бездействие) и решения суда; 6) участвовать в заседании судов апелляционной, кассационной и надзорной инстанций.

В данном перечне прав законного представителя несовершеннолетнего подозреваемого, обвиняемого, подсудимого отсутствует право не свидетельствовать против представляемого лица. Необходимо заметить, что законный представитель несовершеннолетнего подозреваемого, обвиняемого, подсудимого вправе давать показания и при его согласии может быть допрошен в качестве свидетеля, при этом ему разъясняются права, указанные в ч. 4 ст. 56 УПК РФ, в том числе и право отказаться свидетельствовать против самого себя, своего супруга (своей супруги) и других близких родственников. Так, В. Панкратов отмечал, что для решения проблемы свидетельского иммунитета и в первую очередь защиты интересов законных представителей необходимо последних наделить правом не давать показания об обстоятельствах, ставящих их и представляемое лицо в опасность изобличения в совершении преступления [13, с. 25].

Думается, что для многих несовершеннолетних, находящихся под опекой и попечительством, их опекуны и попечители заменяют по сути родителей. Между ними возникают близкие, доверительные отношения. Следовательно, необходимо наделить относительным свидетельским иммунитетом опекунов, попечителей несовершеннолетних подозреваемых, обвиняемых, подсудимых. Представляется, что с учетом изложенного ч. 2 ст. 426 и ч. 1 ст. 428 УПК РФ следует дополнить пунктами следующего содержания: «Законные представители вправе отказаться свидетельствовать против представляемого лица».
Вызывает интерес позиция ряда авторов относительно реализации прав, предоставленных законным представителям подозреваемого, обвиняемого. В частности, отмечается, что, несмотря на то что привлечение законного представителя несовершеннолетнего к участию по уголовному делу является обязательным (ст. 48 УПК РФ), уголовно-процессуальный закон не содержит специального указания на обязательное его участие в производстве следственных действий, оставляя право выбора за законным представителем (п. 3 ч. 2 ст. 426 УПК РФ). На этом основании данные авторы полагают, что отказ законного представителя от участия в предъявлении несовершеннолетнему обвинения и в его допросе не должен влечь за собой «блокирование производства следственных действий». По их мнению, производство следственных действий при таком отказе вполне допустимо, а законные представители могут воздержаться от реализации любых прав, предоставленных им законом [4, с. 44; 14 , с. 487]. Рассматриваемая позиция представляется спорной, поскольку законный представитель призван оказывать несовершеннолетнему помощь в отстаивании его законных интересов, моральную и психологическую поддержку, активно действовать в его интересах. Отказ законного представителя от участия в уголовном судопроизводстве должен повлечь его отстранение (поскольку его действия наносят ущерб интересам несовершеннолетнего) и привлечение в качестве законного представителя другого лица.

Обращает на себя внимание и сама формулировка п. 3 ч. 2 ст. 426 УПК РФ, закрепляющая право законного представителя несовершеннолетнего подозреваемого, обвиняемого участвовать в его допросе, а также с разрешения следователя в иных следственных действиях, производимых с его участием. Из буквального толкования данной нормы следует, что законный представитель вправе участвовать в следственных действиях только с разрешения следователя. Думается, что данное указание существенно ограничивает право законного представителя надлежащим образом осуществлять защиту прав несовершеннолетних в ходе следственных действий, производимых с их участием. В связи с этим целесообразно исключить положение, предусматривающее усмотрение следователя об участии законного представителя несовершеннолетнего в следственных действиях, и изложить п. 3 ч. 2 ст. 426 УПК РФ в следующей редакции: «Участвовать в допросе несовершеннолетнего подозреваемого, обвиняемо- 
го, а также в иных следственных действиях, производимых с его участием».

Следует отметить, что положение ч. 3 ст. 428 УПК РФ, допускающей рассмотрение уголовного дела в отсутствие законного представителя несовершеннолетнего подсудимого, вступает в противоречие со ст. 48 УПК РФ, согласно которой его участие в уголовном деле обязательно. Совершенно верно отмечает Е. В. Марковичева, что принятие судом решения о рассмотрении уголовного дела в отсутствие законного представителя способно привести к нарушению прав несовершеннолетних [15, с. 88]. Считаю необходимым ч. 3 ст. 428 УПК РФ исключить.

Анализ пп. 4, 7, 11 ч. 2 ст. 437 УПК РФ позволяет сделать вывод об ограничении прав законного представителя лица, в отношении которого ведется производство о применении принудительной меры медицинского характера в ходе досудебного производства. Так, его участие в следственных действиях возможно только по разрешению следователя, его участие в судебном разбирательстве подобных ограничений не имеет. Поэтому следует внести изменения в формулировку п. 4 ч. 2 ст. 437 УПК РФ, изложив его в следующей редакции: «4) участвовать в следственных действиях, производимых с участием представляемого лица». Также необходимо включить в перечень прав законного представителя лица, в отношении которого ведется производство о применении принудительной меры медицинского характера, право не свидетельствовать против представляемого лица.

Необходимо подчеркнуть, что процессуальный статус законного представителя несовершеннолетнего свидетеля как самостоятельный в УПК РФ не закреплен, отсутствует и указание на то, что его права аналогичны правам представляемого лица, в данном случае - свидетеля. Вместе с тем анализ положений, предусмотренных ст. 56, 167, 191, 195, 280 УПК РФ, позволяет сформулировать следующие права законного представителя несовершеннолетнего свидетеля: 1) отказаться свидетельствовать против представляемого лица; 2) давать показания; 3) заявлять отвод переводчику, участвующему в допросе несовершеннолетнего свидетеля; 4) заявлять ходатайства и приносить жалобы на действия (бездействие) и решения дознавателя, начальника подразделения дознания, начальника органа дознания, органа дознания, следователя, прокурора и суда; 5) участвовать в следственных и иных процессуальных действиях, производимых с участием несовершеннолетнего свидетеля;
6) знакомиться с протоколами следственных действий, в которых он принимал участие, делать письменные замечания о правильности и полноте сделанных в них записей; 5) заявлять ходатайство о явке на допрос несовершеннолетнего свидетеля с адвокатом; 7) ходатайствовать о применении мер безопасности. Законный представитель несовершеннолетнего свидетеля может быть отстранен от участия в уголовном судопроизводстве на основании постановления дознавателя, следователя, суда, если его участие противоречит интересам несовершеннолетнего или если его действия наносят ущерб интересам несовершеннолетнего.

Представляется логичным закрепить процессуальный статус законных представителей несовершеннолетних свидетелей в самостоятельной статье УПК РФ, изложив ее в следующей редакции: “56 ${ }^{1}$ Законные представители несовершеннолетнего свидетеля:

1. Законные представители несовершеннолетнего свидетеля привлекаются к обязательному участию в уголовном деле на основании постановления следователя либо суда.

2. Законный представитель вправе:

1) отказаться свидетельствовать против представляемого лица;

2) давать показания;

3) заявлять отвод переводчику, участвующему в допросе несовершеннолетнего свидетеля;

4) заявлять ходатайства и приносить жалобы на действия (бездействие) и решения дознавателя, начальника подразделения дознания, начальника органа дознания, органа дознания, следователя, прокурора и суда;

5) участвовать в следственных и иных процессуальных действиях, производимых с участием несовершеннолетнего свидетеля;

6) знакомиться с протоколами следственных действий, в которых он принимал участие, делать письменные замечания о правильности и полноте сделанных в них записей;

7) заявлять ходатайство о явке на допрос несовершеннолетнего свидетеля с адвокатом;

8) ходатайствовать о применении мер безопасности.

3. Законный представитель не вправе:

1) уклоняться от явки по вызовам дознавателя, следователя или в суд;

2) разглашать данные предварительного расследования, ставшие ему известными в связи с участием в производстве по уголовному делу, если он был об этом заранее предупрежден в порядке, установленном статьей 161 настоящего Кодекса. 
4. Законный представитель несовершеннолетнего свидетеля отстраняется от участия в уголовном судопроизводстве на основании постановления дознавателя, следователя, суда, если его участие противоречит интересам несовершеннолетнего или если его действия наносят ущерб интересам несовершеннолетнего» .

Предназначение законного представителя в уголовном судопроизводстве заключается в том, чтобы быть дополнительной гарантией обеспечения процессуальных прав несовершеннолетнего участника уголовного судопроизводства.

Анализ норм, регулирующих положение законного представителя, позволяет сформулировать ряд предложений по совершенствованию его процессуального статуса.

Во-первых, следует внести изменения в п. 12 ст. 5 УПК РФ, изложив его в следующей редакции: законные представители - «родители, усыновители, близкие родственники, родственники и близкие лица; опекуны или попечители; представители уч- реждений или организаций, на попечении которых находится несовершеннолетний участник уголовного судопроизводства (подозреваемый, обвиняемый, подсудимый, потерпевший, свидетель); органы опеки и попечительства» .

Во-вторых, унифицировать процессуальный статус законного представителя применительно ко всем несовершеннолетним участникам уголовного судопроизводства невозможно, поскольку его права зависят от процессуального статуса представляемого несовершеннолетнего лица, от выполняемых им функций (подозреваемый, обвиняемый, подсудимый - функция защиты, потерпевший - функция обвинения, свидетель вспомогательная фрункция). Несмотря на это, в процессуальном статусе законного представителя можно выделить общие положения, характеризующие его задачи и полномочия в уголовном судопроизводстве, закрепив их в соответствующих статьях уголовно-процессуального закона, а именно в ст. $45,56^{1}, 426,428,437$.

\section{СПИСОК ИСПОЛЬЗОВАННОЙ ЛИТЕРАТУРЫ}

1. Мельникова Э. Б. Ювенальная юстиция. Проблемы уголовного права, уголовного процесса и криминологии / Э. Б. Мельникова. - М. : Дело, 2001. - 272 с.

2. Ожегов С. И. Толковый словарь русского языка / С. И. Ожегов, Н. Ю. Шведова. - 4-е изд. - М. : ИТИ Технология, 2003. - 944 с.

3. Защита прав и ответственность несовершеннолетних: современные проблемы / В. Н. Хорьков, Т. С. Волчецкая, С. В. Лонская, Г. В. Казакова. - Калининград : Изд-во Калинингр. гос. ун-та, 2004. - 281 с.

4. Ларинков А. А. Участие в ходе предварительного расследования законных представителей несовершеннолетних подозреваемых, обвиняемых / А. А. Ларинков / / Криминалистъ. - 2010. - № 2. - С. 41-46.

5. Шлипкина А. Б. Сравнительно-правовой анализ института законного представительства по уголовно-процессуальному законодательству РФ и стран СНГ / А. Б. Шлипкина / / Известия Тульского государственного университета. Экономические и юридические науки. - 2013. - № 3-2. - С. 245-251.

6. Баев А. А. Представитель как субъект реализации конституционной гарантии на получение квалифицированной юридической помощи в уголовном судопроизводстве : автореф. дис. ... канд. юрид. наук : 12.00.09/ А. А. Баев. - Краснодар, 2016. - 27 с.

7. Назарчук А. Г. Роль и участие законных представителей несовершеннолетних подозреваемых (обвиняемых) в уголовном процессе / А. Г. Назарчук / / Общество и право. - 2009. - № 2. - С. 201-205.

8. Марковичева Е. В. Проблемы назначения и замены законного представителя несовершеннолетнего в российском уголовном процессе / Е. В. Марковичева / / Судья. - 2015. - № 7. - С. 24-26.

9. Мазюк Р. В. Процессуальная функция законного представителя несовершеннолетнего подозреваемого, обвиняемого в российском уголовном судопроизводстве / Р. В. Мазюк // Ювенальные технологии как основа системной помощи семье и детям : материалы 1-й регион. науч.-практ. конф., г. Усть-Илимск, 24 апр. 2014 г. - Иркутск : Изд-во БГУЭП, 2015. - С. 125-130.

10. Гуськова А. П. Уголовно-процессуальные вопросы организации ювенального судопроизводства в современной России / А. П. Гуськова, В. А. Емельянов, Л. В. Юрченко. - Оренбург : Изд. центр ОГАУ, 2009. 214 c.

11. Марковичева Е. В. Уголовное судопроизводство в отношении несовершеннолетних: проблемы теории и практики / Е. В. Марковичева. - Орел : Изд-во Орл. гос. ун-та, 2011. - 424 с.

12. Шлипкина А. Б. Совершенствование процедуры выбора законного представителя несовершеннолетнего подозреваемого, обвиняемого, подсудимого / А. Б. Шлипкина // Приволжский научный вестник. 2013. - № 11. - С. 114-116.

13. Панкратов В. О свидетельском иммунитете законных представителей / В. Панкратов // Советская юстиция. - 1993. - № 7. - С. 25.

14. Коротков А. П. 900 ответов на вопросы прокурорско-следственных работников по применению УПК PФ: комментарий / А. П. Коротков, А. В. Тимофеев. - М. : Экзамен, 2004. - 576 с.

15. Марковичева Е. В. Проблемы законного представительства в российском уголовном процессе / Е. В. Марковичева // Вестник РГУ им. И. Канта. Сер.: Экономические и юридические науки. - 2008. Вып. 9. - C. 85-91. 


\section{REFERENCES}

1. Mel'nikova E. B. Yuvenal' naya yustitsiya. Problemy ugolovnogo prava, ugolovnogo protsessa $i$ kriminologii [Juvenila Judiciary. Problems of Criminal Law, Criminal Process and Criminology]. Moscow, Delo Publ., 2001. 272 p.

2. Ozhegov S. I., Shvedova N. Yu. Tolkovyi slovar' russkogo yazyka [The Explanatory Dictionary of the Russian Language]. $4^{\text {th }}$ ed. Moscow, ITI Tekhnologiya Publ., 2003. 944 p.

3. Khor'kov V. N., Volchetskaya T. S., Lonskaya S. V., Kazakova G. V. Zashchita prav i otvetstvennost' nesovershennoletnikh: sovremennye problemy [Protection of Rights and Liability of Minors: Current Issues]. Kaliningrad State University Publ., 2004. 281 p.

4. Larinkov A. A. Participation of Lawful Representatives of Suspects, Witnesses in Preliminary Investigation. Criminalist" = Criminalist, 2010, no. 2, pp. 41-46. (In Russian).

5. Shlipkina A. B. The legal comparative analysis of the institute of the legal representation in criminal procedure of Russian Federation and CIS. Izvestiya Tul'skogo gosudarstvennogo universiteta. Ekonomicheskie i yuridicheskie nauki $=$ Proceedings of the Tula State University. Economics and Law, 2013, no. 3-2, pp. 245-251. (In Russian).

6. Baev A. A. Predstavitel' kak sub"ekt realizatsii konstitutsionnoi garantii na poluchenie kvalifitsirovannoi yuridicheskoi pomoshchi v ugolovnom sudoproizvodstve. Avtoref. Kand. Diss. [A Representative as a Subject of Implementation of the Constitutional Guarantee for Getting a Qualified Legal Assistance in Criminal Legal Process. Cand. Diss. Thesis]. Krasnodar, 2016. 27 p.

7. Nazarchuk A. G. The Role and Participation of Legal Representatives of Minor Suspects (the Accused) in Criminal Process. Obshchestvo i pravo = Society and Law, 2009, no. 2, pp. 201-205. (In Russian).

8. Markovicheva E. V. The Problems of Appointing and Change of the Legal Representative of a Minor in Russian Criminal Proceedings. Sudya = Judge, 2015, no. 7, pp. 24-26. (In Russian).

9. Mazyuk R. V. Procedural Function of the Legal Representative of a Minor Suspect, Accused under the Russian Criminal Justice Process. Yuvenal'nye tekhnologii kak osnova sistemnoi pomoshchi sem'e i detyam. Materialy 1-i regional' noi nauchno-prakticheskoi konferentsii, g. Ust'-llimsk, 24 aprelya 2014 g. [Juvenile Technologies as the Basis of the Comprehensive Assistance to the Family and Children. Proceedings of the $1^{\text {st }}$ Regional Scientific and Practical Conference, the town of Ust-llimsk, 24 April 2014]. Irkutsk, Baikal State University of Economics and Law Publ., 2015, pp. 125-130. (In Russian).

10. Gus'kova A. P., Emel'yanov V. A., Yurchenko L. V. Ugolovno-protsessual'nye voprosy organizatsii yuvenal' nogo sudoproizvodstva v sovremennoi Rossii [Criminal Proceedings Issues of the Juvenile Justice in Moden Russia]. Orenburg State Agrarian University Publ., 2009. 214 p.

11. Markovicheva E. V. Ugolovnoe sudoproizvodstvo $v$ otnoshenii nesovershennoletnikh: problemy teorii $i$ praktiki [Criminal Justice Process Regarding Minors: Problems of Theory and Practice]. Orel State University Publ., $2011.424 \mathrm{p}$.

12. Shlipkina A. B. Improving the Procedure of Selection of the Legal Representative of the Minor Suspect, Accused, Defendant. Privolzhskii nauchnyi vestnik = Privolzhsky Scientific Bulletin, 2013, no. 11, pp. 114-116. (In Russian).

13. Pankratov V. On Witness Immunity of Legal Representatives. Sovetskaya yustitsiya = Soviet Justice, 1993, no. 7, pp. 25. (In Russian).

14. Korotkov A. P., Timofeev A. V. 900 otvetov na voprosy prokurorsko-sledstvennykh rabotnikov po primeneniyu UPK RF: kommentarii [900 Answers to Questions of Procuracy and Investigative Officers Regarding the Use of the Russian Federation Code of Criminal Procedure: Commentary]. Moscow, Ekzamen Publ., 2004. 576 p.

15. Markovicheva E. V. The Problem of Legal Representation in Russian Criminal Proceeding. Vestnik Rossiiskogo Gosudarstvennogo Universiteta im. I. Kanta. Seriya: Ekonomicheskie i yuridicheskie nauki= Bulletin of the Immanuel Kant Russian State University. Series: Economics and Law, 2008, iss. 9, pp. 85-91. (In Russian).

\section{Информация об авторе}

Литвинцева Наталья Юрьевна — кандидат юридических наук, доцент, кафедра уголовного права, криминологии и уголовного процесса, Байкальский государственный университет, 664003, г. Иркутск, ул. Ленина, 11, e-mail: litvintseva_nu@mail.ru.

\section{Для цитирования}

Литвинцева Н. Ю. Законные представители несовершеннолетних участников уголовного судопроизводства / Н. Ю. Литвинцева // Известия Байкальского государственного университета. - 2017. - T. 27, № 4. - C. 568-576. - DOI: $10.17150 / 2500-2759.2017 .27(4) \cdot 568-576$.

\section{Author}

Natalia Y. Litvintseva - PhD in Law, Associate Professor, Criminal Law, Criminology and Criminal Procedure Department, Baikal State University, 11 Lenin St., 664003, Irkutsk, Russian Federation, e-mail: litvintseva_nu@mail.ru.

\section{For citation}

Litvintseva N. Y. Legal Representatives of Minor Participants of Criminal Justice Process. Izvestiya Baykal'skogogosudarstvennog universiteta $=$ Bulletin of Baikal State University, 2017, vol. 27, no. 4, pp. 568576. DOI: $10.17150 / 2500-2759.2017 .27(4) .568-576$. (In Russian). 